\title{
Secondary metabolites produced by endophytic bacteria against the Root-Knot Nematode (Meloidogyne sp.)
}

\author{
VINA MAULIDIA ${ }^{1,2}$, LOEKAS SOESANTO $^{3}$, SYAMSUDDIN $^{4}$, KHAIRAN KHAIRAN ${ }^{5}$, \\ TAKAHIRO HAMAGUCHI ${ }^{6}$, KOICHI HASEGAWA ${ }^{6}$, RINA SRIWATI ${ }^{2, \bullet}$ \\ ${ }^{1}$ Doctoral Program in Agricultural Sciences, Faculty of Agriculture, Universitas Syiah Kuala. Jl. Tgk. Hasan Krueng Kalee No. 3, Banda Aceh 23111, \\ Aceh, Indonesia \\ ${ }^{2}$ Department of Plant Protection, Faculty of Agriculture, Universitas Syiah Kuala. Jl. Tgk. Hasan Krueng Kalee No. 3, Banda Aceh 23111, Aceh, Indonesia \\ Tel.: +62- 651-51977, `email: rinasriwati@unsyiah.ac.id \\ ${ }^{3}$ Department of Agrotechnology, Faculty of Agriculture, Universitas Jenderal Soedirman. Jl. Dr. Suparno No. 1, Purwokerto Utara, Banyumas 53123, \\ Central Java, Indonesia \\ ${ }^{4}$ Department of Agrotechnology, Faculty of Agriculture, Universitas Syiah Kuala. Jl. Tgk. Hasan Krueng Kalee No. 3, Banda Aceh 23111, Aceh, Indonesia \\ ${ }^{5}$ Department of Pharmacy, Faculty of Mathematics and Natural Science, Universitas Syiah Kuala. Jl. Syech Abdurrauf No. 3, Banda Aceh 23111, Aceh, \\ Indonesia \\ ${ }^{6}$ Department of Environmental Biology, College of Bioscience \& Biotechnology, Chubu University. 1200 Matsumoto, Kasugai, Aichi 487-8501 Japan
}

Manuscript received: 20 August 2020. Revision accepted: 19 October 2020.

\begin{abstract}
Maulidia V, Soesanto L, Syamsuddin, Khairan K, Hamaguchi T, Hasegawa K, Sriwati R. 2020. Secondary metabolites produced by endophytic bacteria against the Root-Knot Nematode (Meloidogyne sp.). Biodiversitas 21: 5270-5275. Endophytic bacteria live and colonize in plant tissues without causing disease to their plant host. Among several processes, these bacteria can produce secondary metabolites that can help in the defense of plant host against pathogens. This study aimed to identify endophytic bacteria as biocontrol agents against Meloidogyne sp. in tomato plants. Six endophytic bacteria candidates from the genus Pseudomonas, Arthrobacter, Bacillus, and Serratia were isolated from Solanum Lycopersicum, Psidium guajava, Pinus merkusii, Dendrocalamus asper, Albizia chinensis, and Theobroma cacao L, respectively. The average mortality of Meloidogyne sp. by endophytic bacteria was $70,27 \%$ to $95,46 \%$. From these, Bacillus thuringiensis AK08 produced compounds of the secondary metabolites such as flavonoid, phenol, tannins, terpenoids, steroids, saponins, and alkaloids. The best result of the average incubation period, number of galls in the root, number of nematodes at the root, and the number of nematodes in the soil on tomato plant were shown by B. thuringiensis. The major compounds in GC-MS analysis of B. thuringiensis were cholest-5-en-3-ol (3.beta.)-carbonochloridate (25.35\%). Bacillus thuringiensis not only has rules as bio-insecticide but also has nematicidal effect.
\end{abstract}

Keywords: Bacillus thuringiensis, biocontrol agent, GC-MS analysis, mortality, nematicidal effect

\section{INTRODUCTION}

Endophytic bacteria associated with plant tissues are known to benefit their hosts through growth and for biological protection against diseases. In mutualistic associations, endophytes (i.e. bacteria that colonize plant tissues) are protected from nematode attack by their host plant, which in turn provides shelter and nutrition. These bacteria are potential producers of secondary metabolites (Abdallah et al. 2019; Verma et al. 2019). Seven endophytic bacteria, Aerococcus viridans, Bacillus megaterium, Bacillus subtilis, Pseudomonas chlororaphis, Pseudomonas vesicularis, Serratia marcescens, and Sphingomonas paucimobilis effectively against root-knot nematode (Muthukumar et al. 2017).

Plant-parasitic nematodes (PPN) constitute a serious threat for crops in quantity and quality, causing global crop losses annually. Lower case for biocontrol agents such as endophytic bacteria against PPN is particularly timely given the negative impact of the use of chemical nematicides. Awareness-raising for enhancing biocontrol tactics should be better communicated (Abd-Elgawad and Askary 2020; Liu and Park 2018). Plant-Parasitic
Nematodes (PPN), such as the Root-Knot Nematodes (RKN) (Meloidogyne sp.) secrete cell-wall degrading enzymes (e.g. cellulase, hemicellulases, pectinases) that breakdown plant cell walls, facilitating their invasion. RKN can attack those parts of plants that are below the surface soil, especially roots, tubers, and pods. The symptoms in this part of the plant are known as gall. Moreover, RKN causes a reduction in the efficiency of the root system function, due to which plants can be susceptible to other pathogens such as fungi and bacteria. The severely affected roots are shorter than healthy roots with few lateral roots and root hair, this being caused by nematodes feeding on root cells, and causing tissues disrupted; consequently, translocation of water and nutrient is compromised (Bruzos and Grayston, 2019; Hashem et al. 2011).

According to Munif et al. (2013), the utilization of four endophytic bacteria (Pantoea agglomerans, Cedecea davisae, Enterobacter sp. and Pseudomonas putida) by seed treatment, root immersion, or application of watering to the ground, can suppress the formation of galls from pathogens Meloidogyne incognita to 56\%. Endophytic bacteria such as Bacillus sp., Serratia sp., Paenibacillus sp., Enterobacter sp., and Streptomyces sp. isolated from 
Coffea canephora plant showed significant nematicidal activities (85.8\%) against Meloidogyne incognita (Hoang et al. 2020). Two endophytic bacteria isolated from Piper nigrum L. showed high inhibition (53.6\% to $65.8 \%$ ) against rootknot nematode in vitro, which can be applied as bio-control agents to suppress soil-borne pathogens (Wiratno et al. 2019).

According to Malfanova et al. (2011), Bacillus subtilis was isolated from the hogweed plant Heracleum sosnowskyi, can significantly stimulate the growth of tomato plants and protect the plant against Meloidogyne sp. Endophytic bacteria isolated from the roots of $C$. rotundus are capable of reducing the number of $M$. incognita in the roots as well as reducing the number of galls on the roots of tomato plants infected with $M$. incognita (Pradana et al. 2017). So, it is necessary to identify the secondary metabolites produced by endophytic bacteria against Meloidogyne sp. in tomato plant as biocontrol agent.

\section{MATERIALS AND METHODS}

\section{Procedures}

Culture of the endophytic bacteria

The endophytic bacterial isolates were: Arthrobacter sp. (AM08; MT598017) isolated from Solanum lycopersicum L., plant root, Pseudomonas aeruginosa (AJ14; MT598020), isolated from Psidium guajava L. plant root, Pseudomonas mosselii (AB06; MT598025) isolated from Dendrocalamus asper (Schult with f.) Backer ex Heyne, Bacillus cereus (AP12; MT598023) isolated from Pinus merkusii L. plant root, Bacillus thuringiensis (AK08; MT598028) isolated from Theobroma cacao L. plant root, and Serratia marcescens (AS09; MT598027) isolated from Albizia chinensis L plant root. Bacterial isolates were grown in nutrient agar (NA, branch) media, and incubated at room temperature for 48 hours (Hallman et al. 1997).

\section{Extraction of RKN from Apium graveolens L. roots}

Nematodes extracted from samples of celery roots (Apium graveolens L.) were infected with root purge nematodes using the Baermann funnel method. First roots were cleaned and cut into pieces (1 $\mathrm{cm}$ approximately) and weighed as much as 1 gram. The pieces of roots were soaked in sterile water for $6 \mathrm{~h}$ on the Baermann funnel (Dababat et al. 2007).

\section{In vitro assays of endophytic bacteria against $R K N$}

RKN mortality was determined by the inhibitory test. A cell pellet of endophytic bacteria, previously grown for 48 hours, was dissolved in sterile water. Then $5 \mathrm{~mL}$ of bacterial cell pellet with the density - $10^{\wedge} 3 \mathrm{CFU} \mathrm{mL} \mathrm{mL}^{-1}$ was added to $5 \mathrm{~mL}$ of nematode extract (120 second-stage juveniles (J2)), meanwhile $5 \mathrm{~mL}$ sterile water and $5 \mathrm{~mL}$ of nematode extract for control treatment, followed by $24 \mathrm{~h}$ incubation at $26^{\circ} \mathrm{C}$. Nematode mortality was determined by microscopic observation using Nikon 102 microscope (Deen et al. 2014). Nematodes were considered dead if no movement was observed after mechanical stimulation. The observation of nematode using formula mortality nematodes by (Faria et al. 2013).
Mortality $\%=[($ mortality\% in treatment-mortality\% in control $) /(100$-mortality\% in control $)] \times 100$.

Extraction of secondary metabolites from endophytic bacteria

In order to extract the secondary metabolites, each endophytic bacteria were firstly inoculated in liquid NB media and incubated for 2 days at $120 \mathrm{rpm}$. Later, the bacterial suspension was centrifuged at $3000 \mathrm{rpm}$. Cell pellet was dried in oven at $50^{\circ} \mathrm{C}$ temperature, and suspended with $50 \mathrm{~mL}$ methanol $\mathrm{MeOH}$ ) was air distilled, then the extracted endophytic bacteria can be used for secondary metabolites testing (Shekhawat and Shah, 2013). Extracts were tested for the presence of secondary metabolites such as flavonoids, phenols, tannins, terpenoids, steroids, saponins, and alkaloids (Harborne, 1987).

Qualitative analysis of bacterial secondary metabolites

The qualitative phytochemical analysis was performed by the methods of Harborne (1987), this analysis includes flavonoids, phenols, tannins, terpenoids, steroids, saponins and alkaloids.

\section{Evaluation of nematicidal effect of endophytic bacteria against $R K N$}

The evaluation of the nematicidal effect of endophytic bacteria against Meloidogyne sp. was carried out under greenhouse conditions, susceptible Karina variety of tomatoes was used for the experiment. Tomato seeds were surface sterilized with sodium hypochlorite $(5,25 \% \mathrm{v} / \mathrm{v})$ for 5 minutes, rinsed with sterilized water, and then dried. Seeds were immersed in each bacterial suspension (app. $10^{\wedge} 3 \mathrm{CFU} \mathrm{mL} \mathrm{mL}^{-1}$ ) for 3 hours. Tomato seeds were planted in a $2 \mathrm{~kg}$ polybag containing soil medium and manure (2:1). Meloidogyne sp. (J2) was inoculated. After 3 weeks, tomato plants were collected and the number of galls, number of nematodes at the root, and the number of nematodes in the soil were determined according to (Munif et al. 2013).

\section{$G C-M S$ analysis}

Extract of endophytic bacterium B. thuringiensis AK08 was sent for Gas Chromatography-Mass Spectroscopy analysis. The GC-MS was carried out on TRACE 1300 GC, TSQ 8000 TRIPLE QUADRUPOLE MS fitted with TG $5 \mathrm{MS}(30 \mathrm{~m} \times 0.25 \mathrm{~mm}, 0.25 \mu \mathrm{m})$ column and $\mathrm{S} / \mathrm{SL}$ Injector. The injector temperature was kept at $250^{\circ} \mathrm{C}$ and MS transfer line temperature had kept at $250^{\circ} \mathrm{C}$ along with ion source temperature also $250^{\circ} \mathrm{C}$. The column temperature was programmed between $60^{\circ}-280^{\circ} \mathrm{C}$ at $10^{\circ} \mathrm{C} / \mathrm{min}$ using helium as carrier gas at a carrier flow rate of $1 \mathrm{ml} \mathrm{min}{ }^{-1}$. Injection volume had $1.0 \mu \mathrm{l}$ prepared in

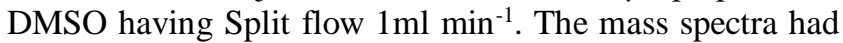
taken at $75 \mathrm{eV}$ with mass scan range from m/z 40-500 amu. The individual constituents were identified by comparing their mass spectra with those of standard using NIST (National Institute of Standards and Technology, U.S. Department of Commerce) compounds (Sparkman et al. 2011). 


\section{Data analysis}

This study used a complete randomized non-factorial design. Data were subjected to perform analysis of variance (ANOVA) and means were separated $(p<0.05)$ by Duncan's Multiple Range Test (DMRT). All analyses were conducted using SPSS version 25.

\section{RESULTS AND DISCUSSION}

Based on the results of nematode mortality percentage, the statistical test showed very significant difference between endophytic bacteria isolates and control (Figure 1) The number followed by different letters is not significant at the level $\alpha 0.05$ (DMRT Test). The treatment of B.thuringiensis exhibited the highest (95.46\%). While $82.93 \%, 81.05 \%, 78.85 \%, 73.36 \%$ and $70.27 \%$ nematode mortality was recorded in $P$. aeruginosa, B. cereus $P$. mosselii, S. marcescens and Arthobacter sp. respectively.

Results of qualitative test revealed that all the six species of endophytic bacteria contain phenols, alkaloids, and tannins (Table 1) Saponins were observed in all five endophytic bacterial species except Arthobacter sp. Only three bacterial species i.e. Arthobacter sp., P. mosselii, and $B$. thuringiensis contain flavonoids. The presence of terpenoids and steroids was observed only in $B$. thuringiensis. Alkaloids were found in all six species of endophytic bacteria by the Dragendorff method. However, in the Meyer method, it was found only in P. aeruginosa and $B$. thuringiensis. In the Wagner method, alkaloids were only found in B. cereus. Species B. thuringiensis produced all secondary metabolites such as flavonoids, phenols, tannins, terpenoids, steroids, saponins, and alkaloids, compared to other endophytic bacterial species, which indicates the most positive secondary metabolite content. B. thuringiensis AK08 showed the highest mortality rate in in vitro test $(95,46 \%)$. This result could be due to highest content in secondary metabolites.

Results of nematicidal effect of endophytic bacteria against RKN revealed that the incubation period (day) control treatment showed the fastest emergence of nematode symptoms at 42 days after planting, while $B$. thuringiensis AK08 treatment had the longest incubation period of 62 days after planting compared with control, with no statistical difference from other treatments (Table 2). The number of galls in root, number of nematodes in root, and in the soil were found lower in all six bacterial species than in control. Of the six endophytic bacterial species B. thuringiensis AK08 showed the most nematicidal effect against RKN. In the observation of the number of galls in the root, the control treatment has the highest (97) number of galls, while in treatment with $B$. thuringiensis AK08 only 36 galls were counted. $B$. thuringiensis AK08 showed the lowest (27) number of nematodes in root whereas in control it was 171. The lowest number of nematodes in the soil was 81 in $B$. thuringiensis AK08 while highest 240 was found in control treatment, which significantly differs from all bacterial treatments.

In this study, methanol $(\mathrm{MeOH})$ was used as extraction solvent since it is the most efficient method for obtainment of secondary metabolites. The methanol $(\mathrm{MeOH})$ extraction was characterized and identified by GC-MS analysis. The interpretation of mass spectrum GC-MS was conducted using the database of National Institute Standard and Technology (NIST) with more than 62,000 patterns. The spectrum of each unknown component was compared with the spectrum of the known components stored in the NIST library. The active principles along with their retention time (Rt), molecular formula, molecular weight, and concentration percentage (area \%) are shown in Tables 3. The GC-MS analysis of bacteria extraction revealed that the steroids were the major compounds in methanol $(\mathrm{MeOH})$ extraction of B.thuringiensis including 5-.alpha.Androst-2-en-17-.beta.-ol, 17-methyl- (13.08\%), cholest-5en-3-ol (3.beta.)-, carbonochloridate (25.35\%), and cholest5-en-3-ol (3.beta.)-, carbonochloridate (17.78\%) (Table 3).

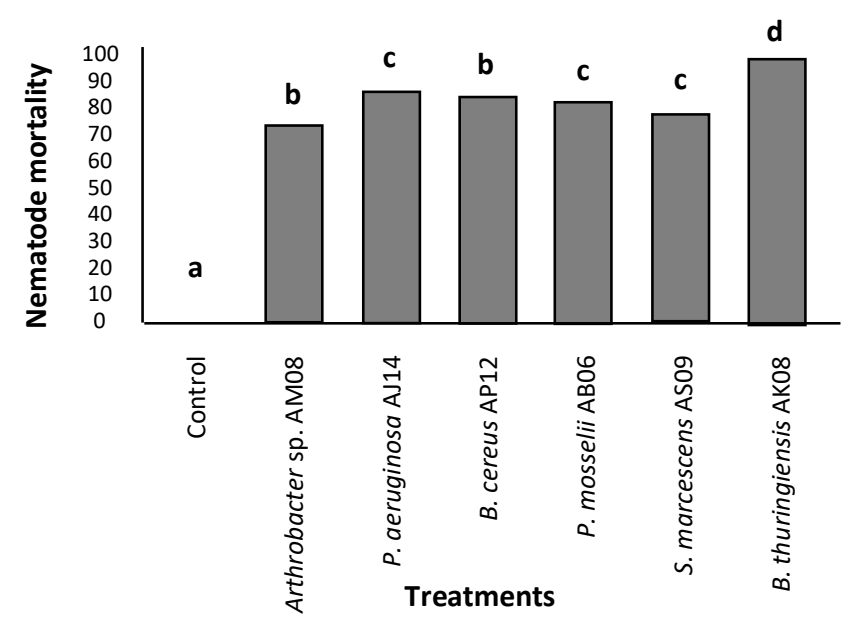

Figure 1. Mortality percentage of Meloidogyne sp. after treatment with endophytes bacteria

Table 1. Qualitative analysis of bacterial secondary metabolites

\begin{tabular}{|c|c|c|c|c|c|c|c|c|c|}
\hline \multirow{3}{*}{$\begin{array}{c}\text { Endophytes bacteria } \\
\text { species }\end{array}$} & \multicolumn{9}{|c|}{ Secondary metabolites } \\
\hline & \multirow[t]{2}{*}{ Flavonoids } & \multirow[t]{2}{*}{ Phenols } & \multirow[t]{2}{*}{ Tannins } & \multirow[t]{2}{*}{ Terpenoids } & \multirow[t]{2}{*}{ Steroids } & \multirow[t]{2}{*}{ Saponins } & \multicolumn{3}{|c|}{ Alkaloids } \\
\hline & & & & & & & D & $\mathbf{M}$ & $\mathbf{W}$ \\
\hline P. aeruginosa (AJ14) & - & + & + & - & - & + & + & + & - \\
\hline Arthrobacter sp. (AM08) & + & + & + & - & - & & + & - & - \\
\hline B. cereus (AP12) & - & + & + & - & - & + & + & - & + \\
\hline P. mosselii (AB06) & + & + & + & - & - & + & + & - & - \\
\hline S. marcescens (AS09) & - & + & + & - & - & + & + & - & - \\
\hline B. thuringiensis (AK08) & + & + & + & + & + & + & + & + & - \\
\hline
\end{tabular}

Note: D: Dragendorff; M: Meyer; W: Wagner 
Table 2. Effect of endophytes bacteria against RKN in tomato plant

\begin{tabular}{lcccc}
\hline \multicolumn{1}{c}{ Treatment } & $\begin{array}{c}\text { Incubation period } \\
\text { (day) }\end{array}$ & $\begin{array}{c}\text { Number of galls } \\
\text { in the root }\end{array}$ & $\begin{array}{c}\text { Number of nematodes } \\
\text { in the root }\end{array}$ & $\begin{array}{c}\text { Number of nematodes } \\
\text { in the soil }\end{array}$ \\
\hline Control & $42 \mathrm{a}$ & $97 \mathrm{~d}$ & $171 \mathrm{e}$ & $240 \mathrm{~b}$ \\
P. aeruginosa (AJ14) & $54 \mathrm{~b}$ & $64 \mathrm{c}$ & $45 \mathrm{~b}$ & $92 \mathrm{a}$ \\
Arthrobacter sp. (AM08) & $56 \mathrm{~b}$ & $55 \mathrm{~b}$ & $55 \mathrm{c}$ & $99 \mathrm{a}$ \\
B. cereus (AP12) & $57 \mathrm{~b}$ & $66 \mathrm{c}$ & $55 \mathrm{c}$ & $107 \mathrm{a}$ \\
P. mosselii (AB06) & $57 \mathrm{~b}$ & $70 \mathrm{c}$ & $85 \mathrm{~d}$ & $102 \mathrm{a}$ \\
S. marcescens (AS09) & $54 \mathrm{~b}$ & $69 \mathrm{c}$ & $76 \mathrm{~d}$ & $96 \mathrm{a}$ \\
B. thuringiensis (AK08) & $62 \mathrm{~b}$ & $36 \mathrm{a}$ & $27 \mathrm{a}$ & $81 \mathrm{a}$ \\
\hline
\end{tabular}

Note: The number followed by different letters are not significant at the level $\alpha 0.05$ (DMRT Test)

Table 3. Compounds identified in the crude methanol extract of B. thuringiensis AK08 by GC-MS analysis

\begin{tabular}{|c|c|c|c|c|}
\hline $\begin{array}{c}\text { No. } \\
\text { peak }\end{array}$ & $\begin{array}{l}\text { Retention } \\
\text { time (min.) }\end{array}$ & $\begin{array}{c}\text { Area } \\
(\%)\end{array}$ & $\begin{array}{c}\text { Molecular } \\
\text { weight }(\mathbf{m} / \mathbf{z})\end{array}$ & Chemical name \\
\hline 1 & 3.541 & 0.33 & 87.05 & 2,2-Dimethoxybutane \\
\hline 2 & 41.490 & 0.22 & 83.00 & n-Pentadecanol \\
\hline 3 & 41.761 & 0.26 & 55.00 & E-14-Hexadecenal \\
\hline 4 & 42.061 & 0.22 & 55.00 & n-Tridecan-1-ol \\
\hline 5 & 43.338 & 0.20 & 149.00 & 1,2-Benzenedicarboxylic acid, monobutyl ester \\
\hline 6 & 43.489 & 0.19 & 57.00 & 3-Eicosene, (E)- \\
\hline 7 & 44.453 & 0.69 & 74.00 & Hexadecanoic acid, methyl ester \\
\hline 8 & 47.326 & 0.32 & 55.00 & trans-2-Decen-1-ol, trifluoroacetate \\
\hline 9 & 47.639 & 1.14 & 83.05 & Behenic alcohol \\
\hline 10 & 47.690 & 1.09 & 57.00 & Octadecane, 1-chloro- \\
\hline 11 & 47.880 & 0.27 & 67.00 & 1,8,11-Heptadecatriene, (Z,Z)- \\
\hline 12 & 47.986 & 0.90 & 55.00 & 6-Octadecenoic acid, methyl ester, (Z)- \\
\hline 13 & 48.461 & 0.24 & 74.00 & Hexacosanoic acid, methyl ester \\
\hline 14 & 48.495 & 0.39 & 143.00 & 2-(4-Fluorophenoxy)-N'-(1-styrylethylidene)acethydrazide \\
\hline 15 & 48.607 & 0.30 & 85.00 & Spiro[androst-5-ene-17,1'-cyclobutan]-2'-one, 3-hydroxy-, (3.beta.,17.beta.)- \\
\hline 16 & 50.882 & 13.08 & 105.05 & 5-.alpha.-Androst-2-en-17-.beta.-ol, 17-methyl- \\
\hline 17 & 51.465 & 1.47 & 91.05 & $\begin{array}{l}\text { 2-[4-methyl-6-(2,6,6-trimethylcyclohex-1-enyl)hexa-1,3,5-trienyl]cyclohex-1-en- } \\
\text { 1-carboxaldehyde }\end{array}$ \\
\hline 18 & 51.541 & 1.97 & 215.10 & Androstane-3,17-diol, 17-methyl-, (3.alpha.,5.alpha.,17.beta.)- \\
\hline 19 & 51.826 & 2.18 & 81.00 & Retinol, acetate \\
\hline 20 & 52.168 & 2.55 & 105.05 & Cholest-5-en-3-ol (3.beta.)-, carbonochloridate \\
\hline 21 & 52.475 & 0.64 & 74.00 & 7,10,13-Eicosatrienoic acid, methyl ester \\
\hline 22 & 52.765 & 3.86 & 57.00 & Cholest-22-ene-21-ol, 3,5-dehydro-6-methoxy-, pivalate \\
\hline 23 & 53.554 & 2.83 & 185.00 & $\begin{array}{l}\text { 185.00 2,2-Dimethyl-6-methylene-1-[3,5-dihydroxy-1-pentenyl]cyclohexan-1- } \\
\text { perhydrol }\end{array}$ \\
\hline 24 & 53.646 & 3.00 & 95.00 & $\begin{array}{l}\text { 2-[4-methyl-6-(2,6,6-trimethylcyclohex-1-enyl)hexa-1,3,5-trienyl]cyclohex-1-en- } \\
\text { 1-carboxaldehyde }\end{array}$ \\
\hline 25 & 53.938 & 25.35 & 147.10 & Cholest-5-en-3-ol (3.beta.)-carbonochloridate \\
\hline 26 & 54.750 & 3.32 & 83.00 & Retinol, acetate \\
\hline 27 & 55.293 & 0.58 & 69.00 & Retinoic acid \\
\hline 28 & 56.531 & 17.78 & 81.00 & Cholest-5-en-3-ol (3.beta.)-, carbonochloridate \\
\hline 29 & 57.035 & 1.57 & 105.05 & Isopimara- $9(11), 15$-diene \\
\hline 30 & 57.263 & 3.02 & 349.15 & 2-Naphthalenol, 2,3,4,4a,5,6,7-octahydro-1,4a-dimethyl-7-(2-hydroxy-1-methylethyl) \\
\hline 31 & 57.615 & 0.48 & 143.10 & Androsta-1,4,6-triene-3,17-dione \\
\hline 32 & 57.957 & 4.54 & 145.05 & Cholest-5-en-3-ol (3.beta.)-, carbonochloridate \\
\hline 33 & 58.406 & 1.23 & 105.00 & 10-12-Pentacosadiynoic acid \\
\hline 34 & 59.055 & 0.46 & 278.90 & Terephthalic acid, isobutyl 2,2,2-trichloroethyl ester \\
\hline 35 & 59.392 & 3.34 & 81.00 & Longifolenaldehyde \\
\hline
\end{tabular}

\section{Discussion}

Bacillus thuringiensis AK08 showed promising results in the control of RKN both in vitro and in planta experiments. The mortality rate against RKN was $95,46 \%$ in in vitro trials. Hu et al. (2017) showed similar result with three endophytic bacteria from genus Bacillus, namely $B$. cereus, B. cereus, and B. altitudinis has the highest mortality activity above $90 \%$. According to Bui et al. (2020), Bacillus sp. and Paenibacillus sp. had more than 95\% of mortality activity against $M$. graminicola. Bacillus sp. and Pseudomonas sp. effectively inhibited Meloidogyne sp. in vitro by $59.7 \%$ and $64.1 \%$, respectively. 
Our isolate B. thuringiensis AK08 showed the presence of 7 secondary metabolites while the other isolates were less diverse in metabolite content. The endophytic bacteria play a significant role in the production of bioactive compounds such as alkaloids, steroids, terpenoids, peptides, polyketones, flavonoids, quinols, and phenols (Singh et al. 2017). These compounds also have important roles in therapeutic applications such as anti-cancer, antioxidant, antimicrobial, anti-inflammatory, and immunosuppressive agents. These metabolites can also act as biofilm, toxins, virulence factors (Singh et al. 2019). Secondary metabolites were categorized into alkaloids, benzopyranones, chinones, flavonoids, phenolic acids, quinones, steroids, saponins, tannins, terpenoids, tetralones, xanthones, and many others. The production of bioactive substances by endophytic bacteria, has been directly associated with the host microorganisms, which may include genetic information from higher plants. This allowed them to better adapt to the host plant and perform certain functions, such as protection from various types of pathogens (Gouda et al. 2016).

Bacillus thuringiensis AK08 has effectively controlled the Melydogyne sp. It reduces galls in root and number nematodes in root and in soil and also increases the incubation period on the tomato plant. Hu et al. (2017) used three species of endophytic bacteria i.e. B. cereus BCM2, $B$. cereus $\mathrm{SZ5}$, and B. altitudinis $\mathrm{CCM} 7$ in pot experiment showed similar results that $B$. cereus BCM2 could significantly reduce the number of galls and egg mass from $81.2 \%$ and $75.6 \%$ on tomato roots. Munif et al. (2015), reported that two endophytic bacterial isolates are $\mathrm{MSJ} 1 \mathrm{H}$ and AGS1F, were able to suppress the number of root gall caused by Meloidogyne sp. by $54 \%$ to $67 \%$. Tran et al. (2019), reported that $B$. megaterium significantly inhibited nematodes in the soil and pepper plant from $81.86 \%$ and $73.11 \%$. Various bacterial endophytes reportedly by produce antibiotics (that inhibit pathogen proliferation) (Glick, 2020). According to Vertrivelkalai (2018), endophytic bacteria from genus Bacillus sp. significantly reduced nematode population in soil and root of tomato plants. The mechanisms by which reduction in nematode population may be due to competition for space and nutrients; and mortality of juveniles induced by secondary metabolites such as 2,4 Diacetylphloroglucinol, lytic enzymes, antibiotics, hydrogen cyanide, and toxic metabolites like bacillopeptidase, subtillin $E$ and $\beta$ lactamase that produced by Bacillus sp. (Dunne et al. 1998).

The GC-MS analysis revealed that the steroid compounds were predominant constituents in the methanolic $B$. thuringiensis extract. The major compounds reported in methanolic extract of B.thuringiensis were androstane and cholestane. Androstane is a steroid compound with a gonane core and contain 19 of carbon (C$19)$, and can exist as either of two isomers, known as $5 \alpha$ androstane and $5 \beta$-androstane. An orally bioavailable adrenal steroid analog with potential antineoplastic activity. Cholestane, is a saturated tetracyclic triterpene contain 27 of carbon (C-27), and available in low abundance in Rhodopyhtes organism, this compound, in general, has antineoplastic activity. Cholestone mostly fragmented at $\mathrm{m} / \mathrm{z} 217$ (from molecular ion 372). This specific fragment, first looks for the 372 molecular ions of cholestane, and then fragments that molecular ion further to its $\mathrm{m} / \mathrm{z} 217$ fragments in order to improve identification of specific isomers. Gas chromatography-mass spectrometry (GC-MS) analysis of 6-chlorohydroxyquinol; 2,3,4,6-tetrachlorophenol and tetrachloro-hydroquinone using mixed culture of B. cereus and S. marcescens (Singh et al. 2009). [1,2- $\alpha$ ] pyrazine-1,4-dione, 3-Keto-1- aza-2,3-dihydrobenzopyran, 3-(4-pyridyl) acrylic acid, 9-octadecenoic acid (Z)-methyl ester, and dioctyl hexanedioate. Abdallah et al. (2016) identified key compounds using GC-MS analysis in bioactive chloroform extracts of B. cereus, which belonged to the family of phytic acid. The other compounds identified are phenol 3,5-dimethoxy, benzoic acid 3,5dihydroxy,2-hydroxy-1- isoindolinone, 3-isobutylhexahydropyrrolo. Beta phenylethyl butyrate, Benzene acetic acid, Mefenoxam antimicrobial compounds that produce by Arthobacter sp. (Munaganti et al. 2016). B. thuringiensis produces crystal proteins which have nematicidal effect against plant-parasitic nematodes such as Bursaphelenchus xylophilus, M. hapla, Pratylenchus scribneri, Tylenchorhynchus sp., and Ditylenchus destructor (Huang et al. 2018; Quan et al. 2008). In general, B. thuringiensis performed best and seen as a biocontrol agent for Meloydogyne sp. on tomato plants. Although $B$. thuringiensis is described as bio-insecticide, our results showed that is also capable of nematode control, being its nematicidal effect due to their secondary metabolites content such as cholest-5-en-3-ol (3.beta.), carbonochloridate which inhibits the nematodes growth.

\section{ACKNOWLEDGEMENTS}

This work was supported and funded by the Ministry of Research, Technology and Higher Education of Republic of Indonesia by Program Magister Menuju Doktor untuk Sarjana Unggul (PMDSU) and Peningkatan Kualitas Publikasi Internasional (PKPI) scheme No. 71/UN11.2/PP/SP3/2018. The authors would like acknowledge to Yusmaini, Afriyani, Siti Fadhila, Rezekinta, Risma, Hawa Celala Purnama, and Khairun Saddami for helping authors to conduct this research.

\section{REFERENCES}

Abd-Elgawad MMM, Askary TH. 2020. Factors affecting success of biological agents used in controlling the plant-parasitic nematodes. Egyptian Journal of Biological Pest Control 30. DOI: 10.1186/s41938-020-00215-2.

Abdallah ABR, Jabnoun KH, Daami RM. 2019. Exploring the beneficial endophytic microorganisms for plant growth promotion and crop protection: Elucidation of some bioactive secondary metabolites involved in both effects. In: Singh HB, Keswani C, Reddy MS, Sansinenea E, García EC. (eds.). Secondary Metabolites of Plant Growth Promoting Rhizomicroorganisms. Springer, Singapore. DOI: 10.1007/978-981-13-5862-3_16.

Abdallah ABR, Mokni TS, Nefzi A, Jabnoun KH, Daami RM. 2016. Biocontrol of Fusarium wilt and growth promotion of tomato plants 
using endophytic bacteria isolated from Nicotiana glauca organs. Biological Control 97: 80-88. DOI: 10.1016/j.biocontrol.2016.03.005

Bruzos M, Grayston SJ. 2019. Biological control of nematodes by plant growth-promoting rhizobacteria: Secondary Metabolites involved and potential applications. In: Singh HB, Keswani C, Reddy MS, Sansinenea E, García EC. (eds.), Secondary Metabolites of Plant Growth Promoting Rhizomicroorganisms. Springer, Singapore. DOI: 10.1007/978-981-13-5862-3 13

Bui HX, Hadi BAR, Oliva R, Schroeder NE. 2020. Beneficial bacterial volatile compounds for the control of root-knot nematode and bacterial leaf blight on rice. Crop Protect 135: 104792. DOI: 10.1016/j.cropro.2019.04.016

Dababat AEFA, and Sikora RA. 2007. Influence of the mutualistic endophyte Fusarium oxysporum 162 on Meloidogyne incognita attraction and invasion. Nematology 9: 771-776.

Deen NEAH, Andras F, Amal FEB. 2014. Nematicidal activity of entomopathogenic bacteria against root-knot nematodes, Meloidogyne incognita in-vitro. Intl J Adv Res 6: 708-713.

Dunne C, Moenne LY, Carthy MJ, Higgins P, Powell J, Dowing DN, and Gara FO. 1998. Combining proteolytic and phloroglucinol-producing bacteria for improved biocontrol of Pythium mediated damping-off of sugarbeet. Plant Pathol 47: 299-307.

Faria JMS, Barbosa P, Bennett RN, Mota M, Figueiredo AC. 2013 Bioactivity against Bursaphelenchus xylophilus: Nematotoxics from essential oils, essential oils fractions, and decoction waters. Phytochemistry 94: 220-228. DOI: 10.1016/j.phytochem.2013.06.005

Glick BR. 2020. Beneficial plant-bacterial interactions. Springer International Publishing, Cham. DOI: 10.1007/978-3-030-44368-9

Gouda S, Das G, Sen SK, Shin HS, Patra JK. 2016. Endophytes: A treasure house of bioactive compounds of medicinal importance. Front Microbiol 7: 1-8. DOI: 10.3389/fmicb.2016.01538

Hallmann J, Quadt-Hallmann A, Mahaffee WF, and Kloepper JW. 1997 Bacterial endophytes in agricultural crops. Canadian J Microbiol 43: 895-914.

Harborne JB. 1987. Secondary metabolism in plant cell cultures. Book. Plant, Cell and Environment 10: 438-438.

Hashem M, and Abo-Elyousr KA. 2011. Management of the root-knot nematode Meloidogyne incognita on tomato with combinations of different biocontrol organisms. Crop Prot 30: 285-292

Hoang H, Tran LH, Nguyen TH, Nguyen DAT, Nguyen HHT, Pham NB Trinh PQ, de Boer T, Brouwer A, Chu HH. 2020. Occurrence of endophytic bacteria in Vietnamese robusta coffee roots and their effects on plant-parasitic nematodes. Symbiosis 80: 75-84. DOI: 10.1007/s13199-019-00649-9

Hu HJ, Chen YL, Wang YF, Tang YY, Chen SL, Yan SZ. 2017 Endophytic Bacillus cereus effectively controls Meloidogyne incognita on tomato plants through rapid rhizosphere occupation and repellent action. Plant Dis 101: 448-455. DOI: 10.1094/PDIS-06-160871-RE

Huang T, Lin Q, Qian X, Zheng Y, Yao J, Wu H, Li M, Jin X, Pan X, Zhang L, Guan X. 2018. Nematicidal activity of Cry1Ea11 from Bacillus thuringiensis BRC-XQ12 against the pinewood nematode (Bursaphelenchus xylophilus). Phytopathology 108: 44-51. DOI: 10.1094/PHYTO-05-17-0179-R

Liu W, Park SW. 2018. Underground mystery: Interactions between plant roots and parasitic nematodes. Curr Plant Biol 15: 25-29. DOI 10.1016/j.cpb.2018.11.004

Malfanova N, Kamilova F, Validov S, Shcherbakov A, Chebotar V, Tikhonovich I, Lugtenberg B. 2011. Characterization of Bacillus subtilis HC8, a novel plant-beneficial endophytic strain from gian hogweed: Endophytic Bacillus subtilis from giant hogweed. Microb Biotechnol 4: 523-532. DOI: 10.1111/j.1751-7915.2011.00253.x.

Munaganti RK, Muvva V, Oskay M, Indupalli MD. 2016. Evaluation of antimicrobial metabolites produced by Arthrobacter kerguelensis VLRK_09 by GC-MS analysis. Celal Bayar Üniversitesi Fen Bilimleri Dergisi 12: 355-355. DOI: 10.18466/cbayarfbe.280596.

Munif A, Hallmann J, Sikora RA. 2013. The influence of endophytic bacteria on Meloidogyne incognita. J ISSAAS 2: 68-74.

Munif A, Wibowo AR, Herliyana EN. 2015. Endophytic bacteria from forestry plants as plant growth-promoting and control agent of Meloidogyne sp. on tomato. Fitopatologi Indonesia Journal 11: 179. 186. DOI: $10.14692 /$ jfi.11.6.179

Muthukumar A, Udhayakumar R, Naveenkumar R. 2017. Role of bacterial endophytes in plant disease control. In: Maheshwari DK, Annapurna K. (eds.). Endophytes: Crop Productivity and Protection. Springer International Publishing, Cham. DOI: 10.1007/978-3-31966544-3_7

Pradana AP, Adiwena M, Santoso D, Wijaya R, Murtilaksono A. 2017. Use of endophytic bacteria from roots of Cyperus rotundus for biocontrol of Meloidogyne incognita. Biodiversitas 18 (4): 13081315. DOI: $10.13057 /$ biodiv/d180404.

Quan YZ, Wang QL, Liu B, Zou X, Yu ZN, Sun M. 2008. Bacillus thuringiensis crystal protein toxicity against plant-parasitic nematodes. Chinese J Agric Biotechnol 5: 13-17. doi:10.1017/S1479236208002003

Shekhawat S, Shah G. 2013. Isolation, characterization and determination of antibacterial activity of bacterial and fungal endophytes from Ocimum sanctum and phytochemical analysis. Intl J Pharma Bio Sci 4: 600-607.

Singh HB, Keswani C, Reddy MS, Sansinenea E, García EC. (Eds.), 2019. Secondary metabolites of plant growth-promoting rhizomicroorganisms: Discovery and applications. Springer, Singapore. DOI: 10.1007/978-981-13-5862-3

Singh M, Kumar A, Singh R, Pandey KD. 2017. Endophytic bacteria: a new source of bioactive compounds. 3 Biotech 7 . DOI: 10.1007/s13205-017-0942-z

Singh S, Singh BB, Chandra R, Patel DK, Rai V. 2009. Synergistic biodegradation of pentachlorophenol by Bacillus cereus (DQ002384), Serratia marcescens (AY927692) and Serratia marcescens (DQ002385). World J Microbiol Biotechnol 25: 1821-1828. DOI: 10.1007/s11274-009-0083-6

Sparkman OD, Zelda P, Fulton GK. 2011. Gas Chromatography and Mass Spectrometry: A Practical Guide. Academic Press, New York.

Tran TPH, Wang SL, Nguyen VB, Tran DM, Nguyen DS, Nguyen AD. 2019. Study of novel endophytic bacteria for biocontrol of black pepper root-knot nematodes in the central highlands of Vietnam. Agronomy 9: 714. DOI: 10.3390/agronomy9110714

Verma SK, Kharwar RN, Gond SK, Kingsley KL, White JF. 2019. Exploring endophytic communities of plants: methods for assessing diversity, effects on host development and potential biotechnological applications. In: Verma SK, White JrJF. (eds.), Seed Endophytes. Springer International Publishing, Cham. DOI: 10.1007/978-3-03010504-4_4

Vetrivelkalai, P. 2019. Evaluation of endophytic bacterial isolates against root-knot nematode, Meloidogyne incognita in tomato under glasshouse condition. Intl J Curr Microbiol Appl Sci 8: 2584-2589. DOI: $10.20546 /$ ijcmas.2019.801.271

Wiratno W, Syakir M, Sucipto I, Pradana AP. 2019. Isolation and characterization of endophytic bacteria from roots of Piper nigrum and their activities against Fusarium oxysporum and Meloidogyne incognita. Biodiversitas 4: 1308-1315. doi: 10.13057/biodiv/d180404. 